\title{
Long-Term Pioglitazone Treatment Augments Insulin Sensitivity and PKC- $\varepsilon$ and PKC- $\theta$ Activation in Skeletal Muscles in Sucrose Fed Rats
}

\author{
I. MARKOVÁ ${ }^{1}$, V. ZÍDEK ${ }^{2}$, A. MUSILOVÁ ${ }^{2}$, M. ŠIMÁKOVÁ ${ }^{2}$, P. MLEJNEK $^{2}$, \\ L. KAZDOVÁ ${ }^{1}$, M. PRAVENEC ${ }^{2}$ \\ ${ }^{1}$ Institute for Experimental and Clinical Medicine, Prague, Czech Republic, ${ }^{2}$ Institute of Physiology, \\ Academy of Sciences of the Czech Republic, Prague, Czech Republic
}

Received July 13, 2009

Accepted November 18, 2009

On-line November 20, 2009

\section{Summary}

It has been suggested that thiazolidinediones (TZDs) ameliorate insulin resistance in muscle tissue by suppressing muscle lipid storage and the activity of novel protein kinase $\mathrm{C}$ (nPKC) isoforms. To test this hypothesis, we analyzed long-term metabolic effects of pioglitazone and the activation of nPKC- $\varepsilon$ and $-\theta$ isoforms in an animal model of the metabolic syndrome, the spontaneously hypertensive rat (a congenic SHR strain with wild type $C d 36$ gene) fed a diet with $60 \%$ sucrose from the age of 4 to 8 months. Compared to untreated controls, pioglitazone treatment was associated with significantly increased basal $(809 \pm 36$ vs $527 \pm 47 \mathrm{nmol}$ glucose/g/2h, $\mathrm{P}<0.005)$ and insulinstimulated glycogenesis ( $1321 \pm 62$ vs $749 \pm 60 \mathrm{nmol}$ glucose $/ \mathrm{g} / 2 \mathrm{~h}$, $\mathrm{P}<0.0001)$ in isolated gastrocnemius muscles despite increased concentrations of muscle triglycerides $(3.83 \pm 0.33$ vs $2.25 \pm 0.12$ $\mu \mathrm{mol} / \mathrm{g}, \quad \mathrm{P}<0.005)$. Pioglitazone-treated rats exhibited significantly increased membrane/total (cytosolic plus membrane) ratio of both PKC- $\varepsilon$ and PKC- $\theta$ isoforms compared to untreated controls. These results suggest that amelioration of insulin resistance after long-term pioglitazone treatment is associated with increased activation of PKC- $\varepsilon$ and $-\theta$ isoforms in spite of increased lipid concentration in skeletal muscles.

\section{Key words}

Novel PKC • Pioglitazone • Muscle lipids • Insulin resistance • Rat

\section{Corresponding author}

M. Pravenec, Institute of Physiology, Czech Academy of Sciences, Vídeňská 1083, 14220 Prague 4, Czech Republic. Fax: +420 241064288. E-mail: pravenec@biomed.cas.cz

\section{Introduction}

Thiazolidinediones (TZDs) such as pioglitazone are insulin sensitizing drugs used for the treatment of type 2 diabetes. TZDs improve glycemic control by reducing insulin resistance in target tissues, however, their mechanism of action is not fully understood (Zinn et al. 2008). In skeletal muscles, insulin resistance is often associated with accumulation of intramyocellular lipids. For instance, strong negative correlations between intramyocellular lipids and insulin sensitivity were found in obese nondiabetic and type 2 diabetic subjects (Philips et al. 1996, Forouhi et al. 1999, Perseghin et al. 1999, Kelley et al. 2002) and in animal models of obesity and type 2 diabetes (Divišová et al. 2002, Pravenec et al. 2003, Qi et al. 2005). TZDs were reported to reduce intramyocellular lipids in most studies (Hockings et al. 2003, Jucker et al. 2003, Kim et al. 2003, Koh et al. 2003, Kuhlmann et al. 2003) and accordingly it is possible that intramyocellular lipid reduction might represent the molecular mechanism of TZD-mediated insulin-sensitizing effects in skeletal muscles. Intramyocellular triglycerides are regarded only as a marker of other lipid intermediates such as diacylglycerols or ceramides that could interfere with insulin signaling. Diacylglycerols activate protein kinase $\mathrm{C}$ (PKC) isoforms that can inhibit several steps of the insulin signaling cascade and in addition also downstream metabolic enzymes such as glycogen synthase (SchmitzPeiffer et al. 2002, 2008). PKCs represent a family of proteins with distinct structural and functional features and specifically the novel isoforms nPCK $-\delta,-\varepsilon,-\theta$ and - 
$\eta$ have been implicated in the pathogenesis of insulin resistance and their modulation by TZDs might be important for insulin-sensitizing effects. Especially PKC$\theta$ is highly expressed in skeletal muscles compared to other tissues and is thus considered as an important candidate for regulating glucose homeostasis. In the current study, we tested a hypothesis that TZDs ameliorate insulin resistance in muscle tissue by suppressing muscle lipid storage and the activation of nPKC isoenzymes. Specifically, we analyzed long-term metabolic effects of pioglitazone in an animal model of the metabolic syndrome, the spontaneously hypertensive rat (congenic SHR strain with wild type $C d 36$ gene), fed a diet with $60 \%$ sucrose from the age of 4 to 8 months. The SHR congenic strain of with wild type $C d 36$ gene was selected instead of the SHR that harbors a deletion variant because $C d 36$ is a target gene involved in the insulin-sensitizing actions of pioglitazone (Qi et al. 2002).

\section{Methods}

Animals

The SHR.BN-Il6/Npy (hereafter referred to as SHR-4) congenic strain was derived by transferring a segment of chromosome 4 carrying wild type $C d 36$ from inbred Brown Norway strain (Charles River Laboratories) (BN/Crl) onto the SHR/Ola genetic background. The SHR4 congenic strain is genetically identical to the SHR progenitor strain except for the differential segment of chromosome 4 including Cd36 (Pravenec et al. 1999). SHR- 4 congenic rats of the N8F18 generation were used in the current study. The SHR-4 congenic strain with wild type $C d 36$ was used instead of the SHR strain with a deletion variant of $C d 36$ because $C d 36$ is a target gene involved in the insulin-sensitizing actions of a TZD ligand of PPAR $\gamma$ (Qi et al. 2002). The rats were housed in an airconditioned animal facility and allowed free access to food and water. We fed male SHR-4 controls $(n=9)$ a diet containing $60 \%$ sucrose from the age of 4 months for 120 days. SHR- 4 males in the experimental group $(n=9)$ were fed the same diet supplemented with pioglitazone $(300$ $\mathrm{mg} / \mathrm{kg}$ diet). At the end of the study, rats were killed by decapitation in ad libitum-fed state. All experiments were performed in agreement with the Animal Protection Law of the Czech Republic (311/1997) and were approved by the Ethics Committee of the Institute of Physiology, Czech Academy of Sciences and by the Ethics Committee of the Czech Academy of Sciences, Prague.

\section{Biochemical analyses}

Blood glucose levels were measured by the glucose oxidase assay (Pliva-Lachema, Brno, Czech Republic) using tail vein blood drawn into $5 \%$ trichloracetic acid and promptly centrifuged. Serum triglyceride concentrations were measured by standard enzymatic methods (Pliva-Lachema, Brno, Czech Republic). Serum insulin concentrations were determined using Mercodia Rat Insulin ELISA kit (Mercodia AB, Uppsala, Sweden).

\section{Western blot analysis}

Muscle tissue was homogenized and processed to obtain cytosolic and membrane fraction as described previously (Neckáŕ et al. 2005). Briefly, frozen samples of gastrocnemius muscle were homogenized and centrifuged at 105,000 $\mathrm{g}$ for $60 \mathrm{~min}$. The supernatant was removed as the cytosolic fraction, the sediment (membrane fraction) was resuspended in homogenization buffer containing $1 \%$ Triton X-100, held on ice for $60 \mathrm{~min}$ and then centrifuged at $105,000 \mathrm{~g}$ for further $60 \mathrm{~min}$. Aliquots of both fractions were saved for protein quantification (Lowry assay modified by Peterson), and cytosol and membrane samples were then used for Western blotting. Samples were run on sodium dodecylsulphate polyacrylamide gel electrophoresis. After electrophoresis, proteins were transferred to a nitrocellulose membrane (Amersham Biosciences, Freiburg, Germany). The membranes were then incubated in $5 \%$ dry low-fat milk in Tris-buffered saline with Tween 20 (TTBS, $\mathrm{pH}$ 7.5) for $60 \mathrm{~min}$ at room temperature. After the blocking step, membranes were washed in TTBS buffer and incubated with PKC- $\varepsilon$ and PKC- $\theta$-specific polyclonal primary rabbit antisera (PKC$\varepsilon$ : Sigma, Saint Luis, MO, USA; PKC- $\theta$ : Santa Cruz Biotechnology, Santa Cruz, CA, USA). After further washings, membranes were incubated with the secondary swine anti-rabbit IgG antibody labeled with horseradish peroxidase (Sevapharma, Prague, Czech Republic). Immunoreactive proteins were made visible using chemiluminescence reagents (Amersham Int., Aurora, Ohio, USA) and exposure to autoradiographic film. Scanning and Quantity One softwares (Bio-Rad, Hercules, CA, USA) were used for quantification of the relative abundance of individual PKC isoforms. To ensure the specificity of PKC- $\varepsilon$ and PKC- $\theta$ immunoreactive proteins, prestained molecular weight protein standards (Fluka, Buchs, Switzerland), recombinant human $\mathrm{PKC}-\varepsilon$ and $\mathrm{PKC}-\theta$ standards 
(Sigma), rat brain extracts, and the respective competing immunizing peptides were used.

\section{Skeletal muscle glycogen synthesis}

Glycogen synthesis was determined in isolated gastrocnemius muscle by measuring the incorporation of ${ }^{14} \mathrm{C}-\mathrm{U}$ glucose into glycogen as previously described (Qi et al. 2005). The gastrocnemius muscles were attached to a stainless steel frame in situ at in vivo length by special clips and separated from other muscles and tendons and immediately incubated for $2 \mathrm{~h}$ in KrebsRinger bicarbonate buffer, $\mathrm{pH} 7.4$ that contained $5.5 \mathrm{mM}$ unlabeled glucose, $0.5 \mu \mathrm{Ci} / \mathrm{ml}$ of ${ }^{14} \mathrm{C}-\mathrm{U}$ glucose, and $3 \mathrm{mg} / \mathrm{ml}$ bovine serum albumin (Armour, Fraction V) with or without $250 \mu \mathrm{U} / \mathrm{ml}$ insulin. Glycogen was extracted and glucose incorporation into glycogen determined as previously described (Qi et al. 2005).
A.

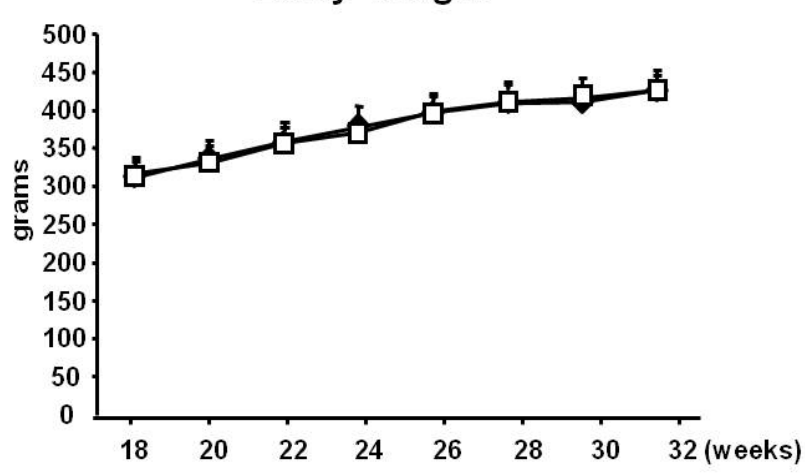

B.

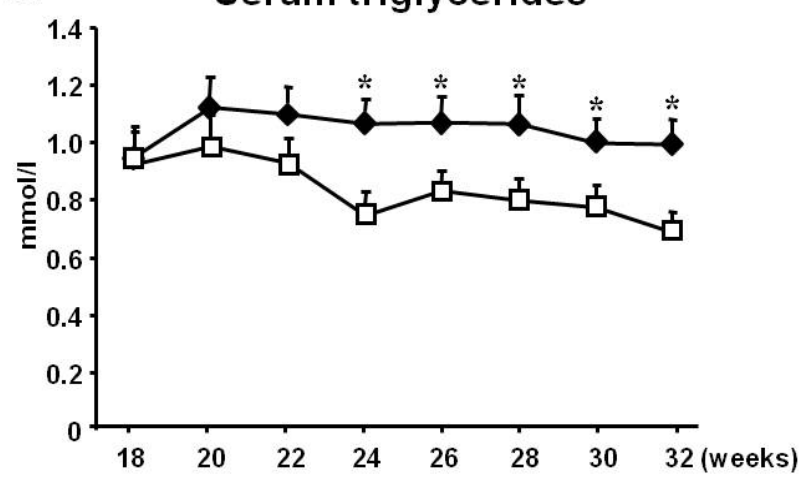

Fig. 1. Effects of long-term pioglitazone treatment on body weight and serum triglyceride levels in SHR-4 rats fed a highsucrose diet. A. Body weights in control rats (solid diamonds) were similar to rats treated with pioglitazone (open squares). B. Serum triglyceride levels were significantly decreased after 6 weeks of pioglitazone treatment compared to control untreated rats (symbols as above). * denotes $\mathrm{P}<0.01$.

\section{Tissue triglyceride measurements}

For triglyceride determination, gastrocnemius muscles were powdered under liquid $\mathrm{N}_{2}$ and extracted for $16 \mathrm{~h}$ in chloroform:methanol, after which $2 \% \mathrm{KH}_{2} \mathrm{PO}_{4}$ was added, and the solution was centrifuged. The organic phase was removed and evaporated under $\mathrm{N}_{2}$. The resulting pellet was dissolved in isopropyl alcohol, and triglyceride content was determined by enzymatic assay (Pliva-Lachema, Brno, Czech Republic).

\section{Statistical analysis}

All data are expressed as means \pm S.E.M. Differences between control and experimental groups were evaluated by paired or non-paired $t$ tests as appropriate. Statistical significance was defined as $\mathrm{p}<0.05$.

A.

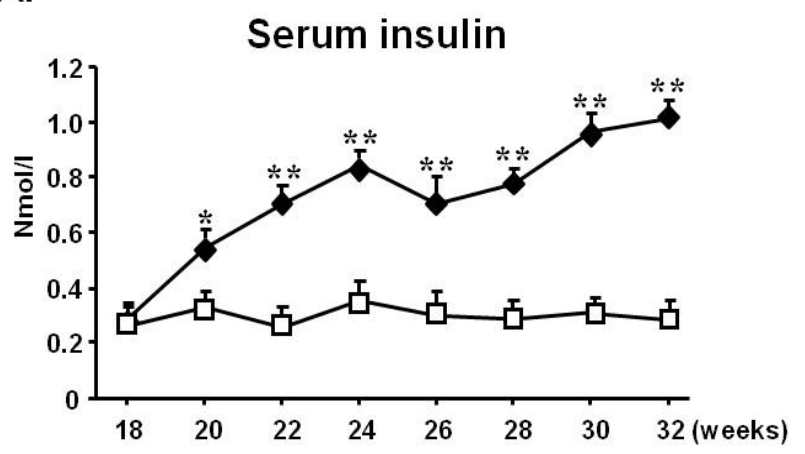

B.

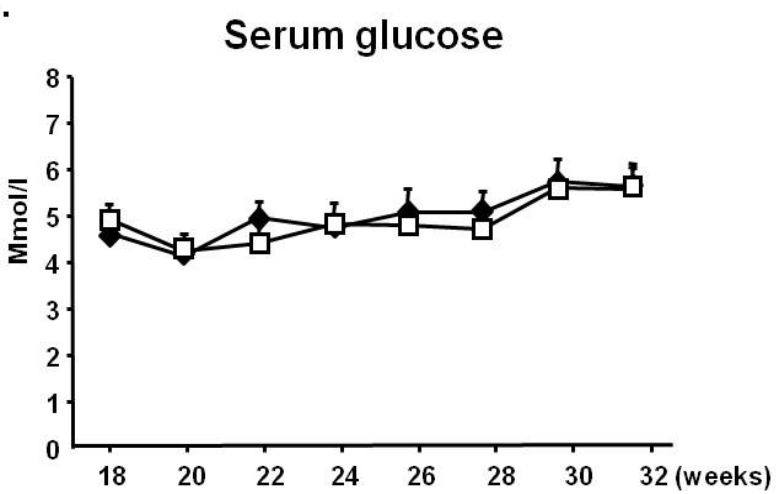

Fig. 2. Effects of long-term pioglitazone treatment on serum insulin and glucose levels in SHR-4 rats fed a high-sucrose diet. A. Serum insulin levels were significantly decreased after two weeks pioglitazone treatment (open squares) when compared to untreated controls (solid diamonds). B. There were no significant differences in blood glucose levels between pioglitazone treated and control rats (symbols as above). * and $* *$ denote $\mathrm{P}<0.0001$ and $\mathrm{P}<0.00001$, respectively. 
A.

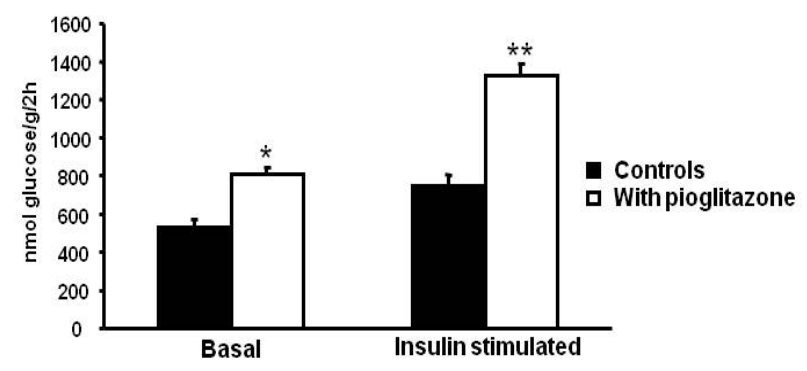

B.

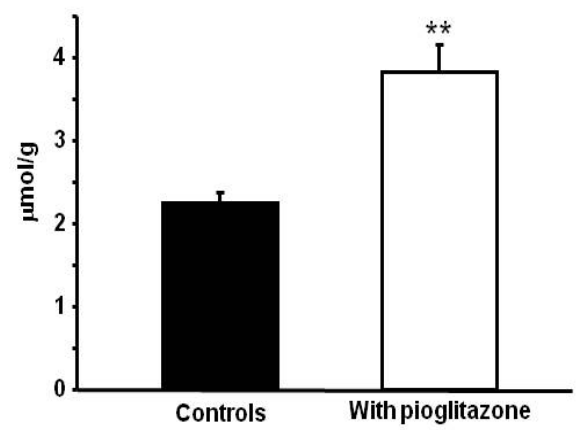

Fig. 3. Effects of pioglitazone treatment on gastrocnemius muscle sensitivity to insulin action and on triglyceride concentration in SHR-4 rats fed a high-sucrose diet. A. Effects of pioglitazone treatment on glycogenesis in isolated gastrocnemius muscles. Basal and insulin-stimulated incorporation of radioactively labeled glucose into muscle glycogen was significantly greater in pioglitazone-treated rats (open bars) when compared to controls (solid bars). B. Triglyceride concentrations in isolated gastrocnemius muscles were significantly greater in pioglitazone treated rats (open bars) when compared to controls (solid bars). * and ** denote $\mathrm{P}<0.005$ and $\mathrm{P}<0.0001$, respectively.

\section{Results}

Body weights in pioglitazone-treated and control rats were similar (Fig. 1A). After 6 weeks of high-sucrose diet feeding, pioglitazone-treated rats exhibited significantly decreased levels of serum triglycerides (Fig. 1B). High sucrose feeding was associated with a progressive increase in serum insulin levels in control rats, while no hyperinsulinemia was observed in pioglitazone-treated rats (Fig. 2A). Both pioglitazonetreated and control rats showed similar normal levels of blood glucose (Fig. 2B). Pioglitazone-treated rats exhibited significant amelioration of insulin resistance in skeletal muscles as estimated from increased basal and insulin-stimulated glycogenesis (Fig. 3A) despite the fact that pioglitazone treatment was associated with increased concentrations of muscle triglycerides (Fig. 3B).
A.

\section{Membrane fraction \\ Cytosolic fraction}

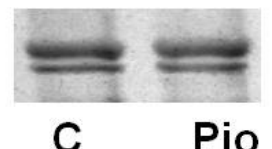

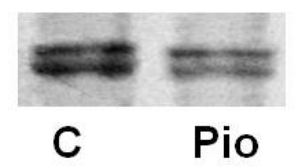

B. PKC epsilon cellular fractions

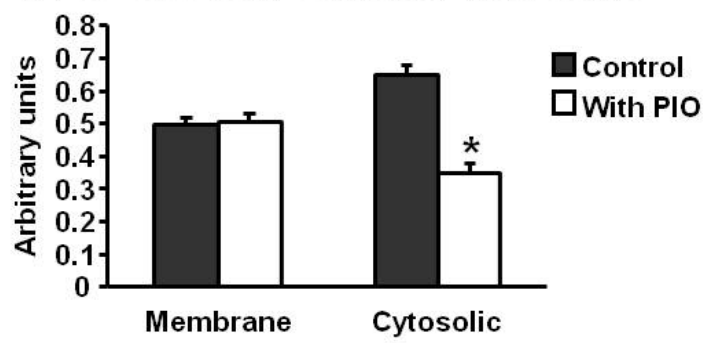

C. PKC epsilon distribution

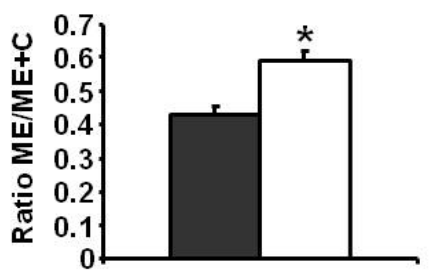

Control

$\square$ With PIO

Fig. 4. The effects of pioglitazone treatment on PKC- $\varepsilon$ activation in gastrocnemius muscle isolated from SHR-4 rats fed a highsucrose diet. A and B. Western blot analysis of PKC- $\varepsilon$ membrane and cytosolic fractions in controls (solid bars) and pioglitazonetreated rats (open bars). There was a significant decrease in the expression of cytosolic fraction in pioglitazone-treated rats. C. Ratio of membrane to total fractions representing the activation of PKC- $\varepsilon$. Pioglitazone treatment was associated with a significant increase in $\mathrm{PKC}-\varepsilon$ activation. * denotes $\mathrm{P}<0.01$.

Pioglitazone treatment was associated with significantly increased ratio of membrane to total PKC- $\varepsilon$ and PKC- $\theta$ proteins (Figs 4 and 5) suggesting activation of both $\mathrm{nPKC}$ isoforms.

\section{Discussion}

In the current study, a long-term pioglitazone treatment of rats fed a high-sucrose diet was associated with amelioration of insulin resistance in gastrocnemius muscles despite the fact that muscle triglyceride concentrations were significantly increased. In addition, amelioration of insulin resistance in skeletal muscles was associated with a significant activation of both PKC- $\varepsilon$ and PKC- $\theta$ as reflected by increased membrane/total ratio of both nPKC isoforms. Contrary to these results, it has 
A.

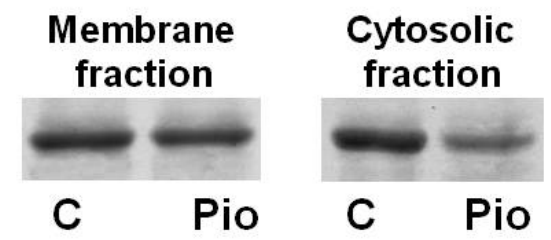

\section{B. PKC theta cellular fractions}

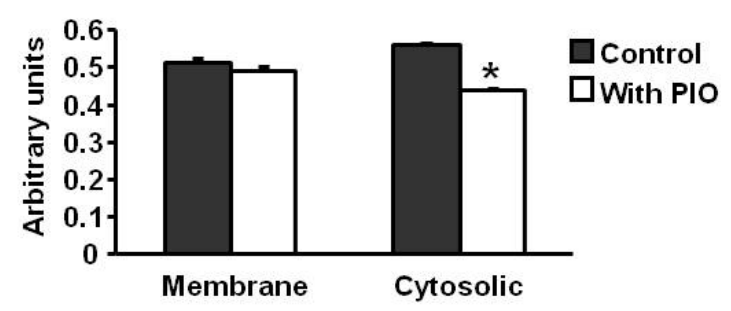

\section{PKC theta distribution}

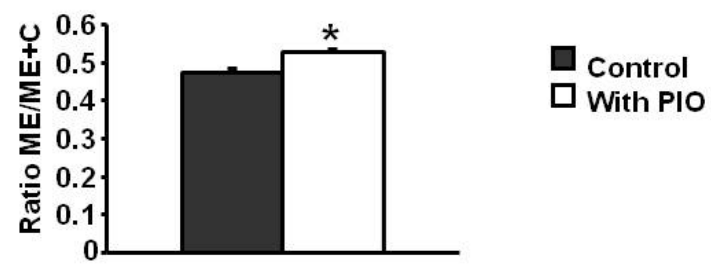

Fig. 5. The effects of pioglitazone treatment on PKC- $\theta$ activation in gastrocnemius muscle isolated from SHR-4 rats fed a highsucrose diet. A and B. Western blot analysis of PKC- $\theta$ membrane and cytosolic fractions in controls (solid bars) and pioglitazonetreated rats (open bars). There was a significant decrease in the expression of cytosolic fraction in pioglitazone-treated rats. C. Ratio of membrane to total fractions representing the activation of PKC- $\theta$. Pioglitazone treatment was associated with a significant increase in PKC- $\theta$ activation. * denotes $\mathrm{P}<0.01$.

been reported that insulin resistance induced by feeding high-fat diets was associated with increased activities of $\mathrm{nPKC}$ isoforms suggesting that activation of nPKC isoforms might inhibit insulin signaling and induce insulin resistance (Schmitz-Peiffer et al. 1997, Yu et al. 2002). On the other hand, studies in PKC- $\theta$ knockout mice demonstrated that the absence of functional PKC- $\theta$ predisposes to obesity and insulin resistance when mice were fed a high-fat diet (Gao et al. 2007). Also transgenic mice with a dominant negative PKC- $\theta$ in skeletal muscle exhibited obesity and insulin resistance (Serra et al. 2003). In addition, PKC- $\varepsilon$ gene knockout mice showed increased serum insulin during i.p. GTT suggesting insulin resistance as compared to wild type controls (Schmitz-Peiffer et al. 2007). These findings are consistent with results of the current study when increased insulin sensitivity in gastrocnemius muscles isolated from pioglitazone-treated rats was associated with PKC- $\theta$ and PKC- $\varepsilon$ activation and provide evidence that $\mathrm{nPKC}$ isoforms are directly involved in regulating muscle sensitivity to insulin action.

Schmitz-Peiffer et al. (1997) reported that a 4-day treatment of Wistar rats fed a high-fat diet with a TZD BRL-49653 was associated with significantly decreased membrane/cytosolic ratio suggesting reduced functional activation of PKC- $\theta$ isoforms in BRL-49653 treated rats. These results are opposite to those reported in the current study when pioglitazone-treated rats exhibited increased membrane/cytosolic ratio. In addition, Lessard et al. (2004) found no significant changes in total or membrane-associated PKC- $\theta$ fraction in soleus muscle isolated from obese Zucker rats fed a standard rat chow and treated for 4 weeks with rosiglitazone when compared to either lean or obese controls. These discrepant results could be explained by studying different types of muscles, different TZDs, different animal models as well as different diets.

TZD treatment is usually associated with significantly decreased intramyocellular lipid levels (Philips et al. 1996, Forouhi et al. 1999, Perseghin et al. 1999, Divišová et al. 2002, Kelley et al. 2002, Pravenec et al. 2003, Qi et al. 2005). According to a widely accepted hypothesis, lipid reducing effects of TZD in skeletal muscles are considered as possible insulinsensitizing mechanisms acting through reducing the activity of especially novel PKC isoforms thereby ameliorating insulin signaling. Surprisingly, in the current study, we observed that long-term pioglitazone treatment was associated with increased triglyceride levels in gastrocnemius muscle, with activation of the PKC- $\varepsilon$ and PKC- $\theta$ isoforms, and with amelioration of insulinstimulated glycogenesis. In addition, pioglitazone-treated rats exhibited significantly decreased levels of serum insulin and triglycerides suggesting amelioration of systemic insulin resistance and dyslipidemia when fed a high-sucrose diet. These findings are similar to results reported by Lessard et al. (2004) who found ameliorated glucose tolerance in obese Zucker rats treated with rosiglitazone despite the fact that these rats exhibited significantly increased intramyocellular triglycerides in soleus muscles when compared to glucose-intolerant controls. The reason for discrepant results regarding TZD effects on skeletal muscle lipid accumulation is unclear. It has been suggested that the effects of TZD on lipid storage might depend on the predominant type of muscle 
fibers. For instance, most of studies showing reduced skeletal muscle lipid content after TZD treatment analyzed muscles with a large percentage of type II fibers, while Lessard et al. (2004) analyzed soleus muscle containing predominantly type I fibers. Gastrocnemius muscle used in the current study, contains both type I and type II fibers, suggesting that differential effects of TZD on lipid storage in skeletal muscle might not depend on the muscle type. It is also possible that increased triglyceride levels in gastrocnemius muscle might be explained by reduced activity of hormone-sensitive lipase (HSL) that is a lipase for diacylglycerols (DAG) (Heammerle et al. 2002). Downregulation of HSL could be associated with increased DAG which might affect activation of PKC. Rosiglitazone treatment was associated with $65 \%$ increase in DAG (Lessard et al. 2004). Both PKC- $\theta$ and PKC- $\varepsilon$ analyzed in the current study are DAG-sensitive.

In conclusion, results of the current study demonstrate that long-term pioglitazone treatment can ameliorate insulin resistance in muscle tissue by mechanisms that might include activation of PKC- $\varepsilon$ and PKC- $\theta$ isoforms and that are independent on reduction in muscle lipid content.

\section{Conflict of Interest}

There is no conflict of interest.

\section{Acknowledgements}

The authors acknowledge the support by grants $1 \mathrm{M} 6837805002$ and ME08006 from the Ministry of Education of the Czech Republic, grant A500110604 from the Grant Agency of the Czech Academy of Sciences, and grants 9387-3, 9359-3, and 9757-4 from the Ministry of Health of the Czech Republic. L.K. is partly supported by the institutional financial support of the Institute for Clinical and Experimental Medicine (MZO 00023001). M. Pravenec is an international research scholar of the Howard Hughes Medical Institute.

\section{References}

DIVIŠOVÁ J, KAZDOVÁ L, HUBOVÁ M, MESCHISVILI E: Relationship between insulin resistance and muscle triglyceride content in nonobese and obese experimental models of insulin resistance syndrome. Ann N Y Acad Sci 967: 440-445, 2002.

FOROUHI NG, JENKINSON G, THOMAS EL, MULliCK S, MIERISOVA S, BHONSLE U, MCKEIGUE PM, BELL JD: Relation of triglyceride stores in skeletal muscle cells to central obesity and insulin sensitivity in European and South Asian men. Diabetologia 42: 932-935, 1999.

GAO Z, WANG Z, ZHANG X, BUTLER AA, ZUBERI A, GAWRONSKA-KOZAK B, LEFEVRE M, YORK D, RAVUSSIN E, BERTHOUD HR, MCGUINNESS O, CEFALU WT, YE J: Inactivation of PKC- $\theta$ leads to increased susceptibility to obesity and dietary insulin resistance in mice. Am J Physiol 292: E84-E91, 2007.

HAEMMERLE G, ZIMMERMANN R, HAYN M, THEUSSL C, WAEG G, WAGNER E, SATTLER W, MAGIN TM, WAGNER EF, ZECHNER R: Hormone-sensitive lipase deficiency in mice causes diglyceride accumulation in adipose tissue, muscle, and testis. J Biol Chem 277: 4806-4815, 2002.

HOCKINGS PD, CHANGANI KK, SAEED N, REID DG, BIRMINGHAM J, O'BRIEN P, OSBORNE J, TOSELAND CN, BUCKINGHAM RE: Rapid reversal of hepatic steatosis, and reduction of muscle triglyceride, by rosiglitazone: MRI/S studies in Zucker fatty rats. Diabetes Obes Metab 5: 234-243, 2003.

JUCKER BM, SCHAEFFER TR, HAIMBACH RE, MAYER ME, OHLSTEIN DH, SMITH SA, COBITZ AR, SARKAR SK: Reduction of intramyocellular lipid following short-term rosiglitazone treatment in Zucker fatty rats: an in vivo nuclear magnetic resonance study. Metabolism 52: 218-225, 2003.

KELLEY DE, GOODPASTER BH, STORLIEN L: Muscle triglyceride and insulin resistance. Annu Rev Nutr 22: 325 346, 2002.

KIM JK, FILLMORE JJ, GAVRILOVA O, CHAO L, HIGASHIMORI T, CHOI H, KIM HJ, YU C, CHEN Y, QU X: Differential effects of rosiglitazone on skeletal muscle and liver insulin resistance in A-ZIP/F-1 fatless mice. Diabetes 52: 1311-1318, 2003.

KOH EH, KIM MS, PARK JY, KIM HS, YOUN JY, PARK HS, YOUN JH, LEE KU: Peroxisome proliferatoractivated receptor (PPAR)-alpha activation prevents diabetes in OLETF rats: comparison with PPAR-gamma activation. Diabetes 52: 2331-2337, 2003. 
KUHLMANN J, NEUMANN-HAEFELIN C, BELZ U, KALISCH J, JURETSCHKE HP, STEIN M, KLEINSCHMIDT E, KRAMER W, HERLING AW: A longitudinal in vivo ${ }^{1} \mathrm{H}$-spectroscopic study in Zucker diabetic fatty rats. Diabetes 52: 138-144, 2003.

LESSARD SJ, LO GIUDICE SL, LAU W, REID JJ, TURNER N, FEBBRAIO MA, HAWLEY JA, WATT MJ: Rosiglitazone enhances glucose tolerance by mechanisms other than reduction of fatty acid accumulation within skeletal muscle. Endocrinology 145: 5665-5670, 2004.

NECKÁŘ J, MARKOVÁ I, NOVÁK F, NOVÁKOVÁ O, SZÁRSZOI O, OŠŤÁDAL B, KOLÁŘ F: Increased expression and altered subcellular distribution of PKC-delta in chronically hypoxic rat myocardium: involvement in cardioprotection. Am J Physiol 288: H1566-H1572, 2005.

PERSEGHIN G, SCIFO P, De COBELli F, PAGLIATO E, BATTEZZATI A, ARCELLONI C, VANZULLI A, TESTOLIN G, POZZA G, DEL MASCHIO A, LUZI L: Intramyocellular triglyceride content is a determinant of in vivo insulin resistance in humans. Diabetes 48: 1600-1606, 1999.

PHILLIPS DIW, CADDY S, ILIC V, FIELDING BA, FRAYN KN, BORTHWICK AC, TAYLOR R: Intramyocellular triglyceride and muscle insulin sensitivity: evidence for a relationship in nondiabetic subjects. Metabolism 45: 947-950, 1996.

PRAVENEC M, ZÍDEK V, ŠIMÁKOVÁ M, KŘEN V, KŘENOVÁ D, HORKÝ K, JÁCHYMOVÁ M, MÍKOVÁ B, KAZDOVÁ L, AITMAN TJ: Genetics of Cd36 and the clustering of multiple cardiovascular risk factors in spontaneous hypertension. J Clin Invest 103: 1651-1657, 1999.

PRAVENEC M, KAZDOVÁ L, LANDA V, ZÍDEK V, MLEJNEK P, JANSA P, WANG J, QI N, KURTZ TW: Transgenic and recombinant resistin impair skeletal muscle glucose metabolism in the spontaneously hypertensive rat. $J$ Biol Chem 278: 45209-45215, 2003.

QI N, KAZDOVÁ L, ZÍDEK V, LANDA V, KŘEN V, PERSHADSINGH HA, LEZIN ES, ABUMRAD NA, PRAVENEC M, KURTZ TW: Pharmacogenetic evidence that Cd36 is a key determinant of the metabolic effects of pioglitazone. $J$ Biol Chem 277: 48501-48507, 2002.

QI NR, WANG J, ZÍDEK V, LANDA V, MLEJNEK P, KAZDOVÁ L, PRAVENEC M, KURTZ TW: A new transgenic rat model of hepatic steatosis and the metabolic syndrome. Hypertension 45: 1004-1011, 2005.

RASOULI N, RAUE U, MILES LM, LU T, Di GREGORIO GB, ELBEIN SC, KERN PA: Pioglitazone improves insulin sensitivity through reduction in muscle lipid and redistribution of lipid into adipose tissue. Am J Physiol 288: E930-E934, 2005.

SCHMITZ-PEIFFER C, BROWNE CL, OAKES ND, WATKINSON A, CHISHOLM DJ, KRAEGEN EW, BIDEN TJ: Alterations in the expression and cellular localization of protein kinase $\mathrm{C}$ isozymes $\varepsilon$ and $\theta$ are associated with insulin resistance in skeletal muscle of the high-fat-fed rat. Diabetes 46: 169-178, 1997.

SCHMITZ-PEIFFER C, OAKES ND, BROWNE CL, KRAEGEN EW, BIDEN TJ: Reversal of chronic alterations of skeletal muscle protein kinase C from fat-fed rats by BRL-49653. Am J Physiol 273: E915-E921, 1997.

SCHMITZ-PEIFFER C: Protein kinase C and lipid-induced insulin resistance in skeletal muscle. Ann N Y Acad Sci 967: 146-157, 2002.

SCHMITZ-PEIFFER C, LAYBUTT DR, BURCHFIELD JG, GURISIK E, NARASIMHAN S, MITCHELL CJ, PEDERSEN DJ, BRAUN U, COONEY GJ, LEITGES M, BIDEN TJ: Inhibition of PKC epsilon improves glucose-stimulated insulin secretion and reduces insulin clearance. Cell Metab 6: 320-328, 2007.

SCHMITZ-PEIFFER C, BIDEN TJ: Protein kinase C function in muscle, liver, and beta-cells and its therapeutic implications for type 2 diabetes. Diabetes 57: 1774-1783, 2008.

SERRA C, FEDERICI M, BUONGIORNO A, SENNI MI, MORELLI S, SEGRATELLA E, PASCUCCIO M, TIVERON C, MATTEI E, TATANGELO L, LAURO R, MOLINARO M, GIACCARI A, BOUCHÉ M: Transgenic mice with dominant negative PKC- $\theta$ in skeletal muscle: a new model of insulin resistance and obesity. J Cell Physiol 196: 89-97, 2003.

YU C, CHEN Y, ZONG H, ZHANG D, ZONG H, WANG Y, BERGERON R, KIM JK, CUSHMAN SW, COONEY GJ, ATCHESON B, WHITE MF, KRAEGEN EW, SHULMAN GI: Mechanism by which fatty acids inhibit insulin activation of IRS-1 associated phosphatidylinositol 3-kinase activity in muscle. J Biol Chem 277: 50230-50236, 2002. 
ZINN A, FELSON S, FISHER E, SCHWARTZBARD A: Reassessing the cardiovascular risks and benefits of thiazolidinediones. Clin Cardiol 31: 397-403, 2008. 